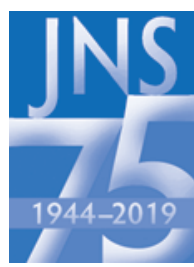

\title{
Spinal instrumentation in infants, children, and adolescents: a review
}

\author{
JNSPG 75th Anniversary Invited Review Article
}

Stephen Mendenhall, MD, ${ }^{1}$ Dillon Mobasser, ${ }^{1}$ Katherine Relyea, $M S,{ }^{2}$ and Andrew Jea, MD, MHA ${ }^{1}$

'Section of Pediatric Neurosurgery, Riley Hospital for Children, Department of Neurological Surgery, Indiana University School of Medicine, Goodman Campbell Brain and Spine, Indianapolis, Indiana; and 'Baylor College of Medicine, Houston, Texas

OBJECTIVE The evolution of pediatric spinal instrumentation has progressed in the last 70 years since the popularization of the Harrington rod showing the feasibility of placing spinal instrumentation into the pediatric spine. Although lacking in pediatric-specific spinal instrumentation, when possible, adult instrumentation techniques and tools have been adapted for the pediatric spine. A new generation of pediatric neurosurgeons with interest in complex spine disorder has pushed the field forward, while keeping the special nuances of the growing immature spine in mind. The authors sought to review their own experience with various types of spinal instrumentation in the pediatric spine and document the state of the art for pediatric spine surgery.

METHODS The authors retrospectively reviewed patients in their practice who underwent complex spine surgery. Patient demographics, operative data, and perioperative complications were recorded. At the same time, the authors surveyed the literature for spinal instrumentation techniques that have been utilized in the pediatric spine. The authors chronicle the past and present of pediatric spinal instrumentation, and speculate about its future.

RESULTS The medical records of the first 361 patients who underwent 384 procedures involving spinal instrumentation from July 1, 2007, to May 31, 2018, were analyzed. The mean age at surgery was 12 years and 6 months (range 3 months to 21 years and 4 months). The types of spinal instrumentation utilized included occipital screws ( 94 cases); C1 lateral mass screws (115 cases); C2 pars/translaminar screws (143 cases); subaxial cervical lateral mass screws (95 cases); thoracic and lumbar spine traditional-trajectory and cortical-trajectory pedicle screws (234 cases); thoracic and lumbar sublaminar, subtransverse, and subcostal polyester bands (65 cases); S1 pedicle screws (103 cases); and S2 alar-iliac/iliac screws (56 cases). Complications related to spinal instrumentation included hardware-related skin breakdown (1.8\%), infection (1.8\%), proximal junctional kyphosis (1.0\%), pseudarthroses $(1.0 \%)$, screw malpositioning $(0.5 \%)$, CSF leak $(0.5 \%)$, hardware failure $(0.5 \%)$, graft migration $(0.3 \%)$, nerve root injury $(0.3 \%)$, and vertebral artery injury (0.3\%).

CONCLUSIONS Pediatric neurosurgeons with an interest in complex spine disorders in children should develop a comprehensive armamentarium of safe techniques for placing rigid and nonrigid spinal instrumentation even in the smallest of children, with low complication rates. The authors' review provides some benchmarks and outcomes for comparison, and furnishes a historical perspective of the past and future of pediatric spine surgery.

https://thejns.org/doi/abs/10.3171/2018.10.PEDS18327

KEYWORDS pediatric spine; spinal instrumentation; review; history

$\mathrm{T}$ HE pediatric spine may be affected by various pathologies, which can be categorized as congenital, developmental, and acquired. These etiologies of pediatric spine disease represent an important distinction from those in adults. The inherent properties of the pedi- atric spine, such as diminutive anatomy, absence of pediatric-specific instrumentation, and inability to extrapolate adult techniques to a child, make the insertion of pediatric instrumentation challenging. A singular problem in the pediatric age group is the restrictive, unwanted effects of

ABBREVIATIONS BMP = bone morphogenetic protein; $\mathrm{PEEK}=$ polyetheretherketone .

SUBMITTED August 31, 2018. ACCEPTED October 4, 2018.

INCLUDE WHEN CITING DOI: 10.3171/2018.10.PEDS18327. 
spinal instrumentation on the skeletally immature spine. Fusing the skeletally immature spine may lead to far more serious issues beyond growth retardation. These issues may include restrictive lung disease, pulmonary hypertension, right heart failure, and death.

This review of our experience and series of pediatric patients describes seldom-used anterior and more often used posterior approaches for the placement of spinal instrumentation in the pediatric spine. It surveys the history of spinal instrumentation in children, beginning with Paul Harrington and his revolutionary treatment for scoliosis in children with polio. Various biomaterials and other surgical adjuncts, such as intraoperative navigation, are considered. Lastly, we briefly survey future directions for pediatric spinal instrumentation.

\section{Methods}

Our experience with the first 384 spinal fusions with instrumentation in children (age $\leq 21$ years) was reviewed from July 1, 2007, to May 31, 2018. Up until July 31, 2016, surgeries were performed at Texas Children's Hospital in Houston, Texas (299 cases); thereafter, procedures were performed at Riley Hospital for Children in Indianapolis, Indiana (85 cases).

\section{Patient Demographics}

There were 361 patients who underwent 384 operative procedures involving spinal instrumentation. Boys accounted for $48.2 \%$ of the population. The mean age at the time of surgery was 12 years and 6 months (range 3 months to 21 years and 4 months). The indications for spinal fusion can be divided into degenerative, congenital, trauma, and tumor (Table 1).

\section{Operative Data}

Among surgeries performed, spinal instrumentation was placed at the craniocervical junction (occiput-C2; 142 cases), subaxial cervical spine (C3-7; 99 cases), thoracic spine (T1-9; 129 cases), thoracolumbar junction (T10-L2; 142 cases), lumbar spine (L3-5; 165 cases), sacrum (105 cases), and pelvis (57 cases) (Table 1). Of the 384 cases, 360 were performed from a posterior-only approach, 14 cases were performed from combined anterior and posterior approaches, and 10 cases were performed from an anterior-only approach. It is important to note that anterior-only approaches were limited to cervical spine cases.

The types of spinal fixation devices and techniques used included occipital screws (94 cases); C1 lateral mass screws (115 cases); C2 pars/translaminar screws (143 cases); subaxial cervical lateral mass screws (95 cases); thoracic and lumbar spine traditional-trajectory and corticaltrajectory pedicle screws (234 cases); thoracic and lumbar sublaminar, subtransverse, and subcostal polyester bands (65 cases); S1 pedicle screws (103 cases); and S2 alar-iliac/ iliac screws (56 cases) (Table 1). Based on our experience with spinal instrumentation in children, we describe our personal biases in selecting and placing anchor points in the spine of young children. Stepwise instruction and surgical indications for placement of spinal instrumentation in a child are included in our prior publications. ${ }^{34}$
TABLE 1. Patient demographics and operative data

\begin{tabular}{|c|c|}
\hline & Value \\
\hline \multicolumn{2}{|l|}{ Patient demographics } \\
\hline Patients, $n$ & 361 \\
\hline Spinal fusions, $\mathrm{n}$ & 384 \\
\hline Mean age (range), yrs & $12.5(0.3-21.3)$ \\
\hline Male, $\mathrm{n}(\%)$ & $185(48)$ \\
\hline \multicolumn{2}{|l|}{ Indications for spinal fusion } \\
\hline Degenerative, $\mathrm{n}(\%)$ & $59(15)$ \\
\hline Congenital, n (\%) & $215(56)$ \\
\hline Trauma, n (\%) & $76(20)$ \\
\hline Tumor, n (\%) & $34(9)$ \\
\hline \multicolumn{2}{|l|}{ Location of spinal fusion } \\
\hline Craniocervical junction (Oc-C2), n & 142 \\
\hline Subaxial cervical spine (C3-7), $n$ & 99 \\
\hline Thoracic spine (T1-9), $n$ & 129 \\
\hline Thoracolumbar junction (T10-L2), n & 142 \\
\hline Lumbar spine (L3-5), n & 165 \\
\hline Sacrum, $\mathrm{n}$ & 105 \\
\hline Pelvis, $n$ & 57 \\
\hline \multicolumn{2}{|l|}{ Approach to the spine } \\
\hline Posterior, n (\%) & $360(93)$ \\
\hline Anterior, n (\%) & $10(3)$ \\
\hline Combined, n (\%) & $14(4)$ \\
\hline \multicolumn{2}{|l|}{ Spinal fixation devices \& techniques } \\
\hline Occipital screws, $n$ & 94 \\
\hline C1 lateral mass screws, $n$ & 115 \\
\hline $\mathrm{C} 2$ pars/translaminar screws, $\mathrm{n}$ & 143 \\
\hline Subaxial cervical lateral mass screws, $\mathrm{n}$ & 95 \\
\hline Thoracic/lumbar pedicle screws, $n$ & 234 \\
\hline Sublaminar polyester bands, $n$ & 65 \\
\hline S1 pedicle screws, $n$ & 103 \\
\hline S2 alar-iliac/iliac screws, $n$ & 56 \\
\hline
\end{tabular}

Oc = occiput.

\section{Description of Techniques}

\section{Posterior Spinal Instrumentation}

Craniocervical Junction (occiput-C2)

Occipital Fixation. The zone of failure for occipitocervical instrumentation is usually at the point of fixation to the occiput. A child's head is disproportionately large compared with that of adults, especially in the occipital region. Moreover, the necessity to keep the head and neck in a neutral position rather than flexed, or in a military tuck position, produces an acute angle between the slope of the occiput and the line of the cervical spine. ${ }^{106,112,123}$ These geometric constraints require extreme bends in the rods and subsequent notching of the rods that span occipitocervical fusions. Additionally, the average skull thickness in the occipital region in children is $3.8 \mathrm{~mm}$ compared with $6.7 \mathrm{~mm}$ in adults. ${ }^{4}$ Because of poor screw purchase, thin bone stock, and rod notching, children may be more 

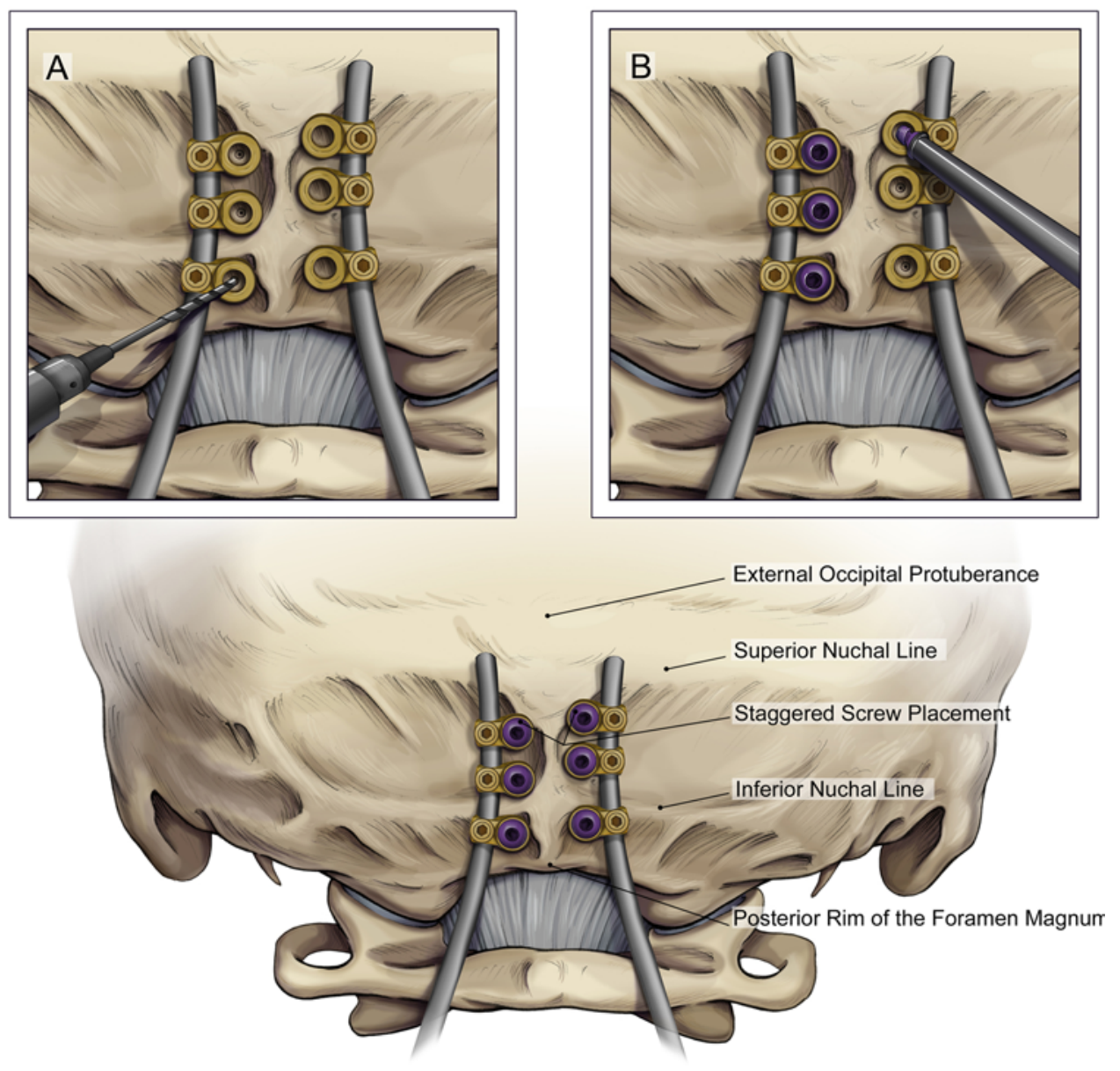

FIG. 1. Occipital fixation. Tapping (A) and placement (B) of occipital screws. The stop-drill technique, which consists of triangulating toward the midline, performed slowly until penetration of the inner table of the skull, is routinely used to prevent dural and sinus laceration. Right- and left-sided screw trajectories are staggered to prevent screw paths from intersecting. Screws are typically placed between the inferior and superior nuchal lines. Screws may be placed in a unicortical fashion near the superior nuchal line to prevent penetration of the transverse sinus. Image created by Katherine Relyea, MS, CMI, and printed with permission from BayIor College of Medicine; first appeared in Chern JJ, et al: Instrumentation and stabilization of the pediatric spine: technical nuances and age-specific considerations, in Quinones-Hinojosa A (ed): Schmidek \& Sweet: Operative Neurosurgical Techniques: Indications, Methods, and Results, ed 6. Philadelphia: Elsevier Saunders, 2012, Vol 1, pp 759-767. Figure is available in color online only.

prone to instrumentation failure at its attachment to the skull. $46,47,110$

Bicortical screw placement between the superior and inferior nuchal lines seems to be superior to unicortical placement in biomechanical studies. ${ }^{56,160}$ On the other hand, bicortical screw placement carries higher risk than unicortical screw placement. With bicortical screw placement, there are risks of durotomy, CSF leakage, dural venous sinus injury, and intracranial hemorrhage. ${ }^{63,127} \mathrm{CSF}$ leakage and venous bleeding from an injured sinus may be stopped by working quickly to place the screw or plugging the hole in the skull with bone wax. Our occipital fixation technique is illustrated in Fig. 1.

Cl Lateral Mass Screws and C1-2 Transarticular Screws. The biomechanically sound Magerl technique ${ }^{69}$ for C1-2 transarticular screw placement traverses 4 cortical surfaces and the C1-2 joint (Fig. 2). However, it is technically demanding and places the vertebral arteries at risk. The rates of vertebral artery injury (2\%-8\%) are likely underreported in the literature. ${ }^{39,45,52,93}$ The use of this technique has been infrequently described in the pediatric spine. ${ }^{52,94,109,145}$

Because of the prohibitive technical and anatomical requirements for the Magerl technique, C1-2 transarticular screws have given way to $\mathrm{C} 1-2$ screw-plate or screw-rod constructs as described by Goel and Laheri, 53,55 and Harms and Melcher, ${ }^{57}$ respectively. The Goel/Harms technique for $\mathrm{C} 1-2$ posterior instrumented fusion may be more applicable even in the smallest of children or those with anatomical variants (Fig. 3).

C1 lateral mass screw placement may itself carry the risks of vertebral artery injury, but our experience and that of others ${ }^{53,57,68,139}$ show that it can be performed safely and be an efficacious part of an atlantoaxial or occipitocervical construct in children.

C2 Pars/Pedicle and Translaminar Screws. C2 pars/ 


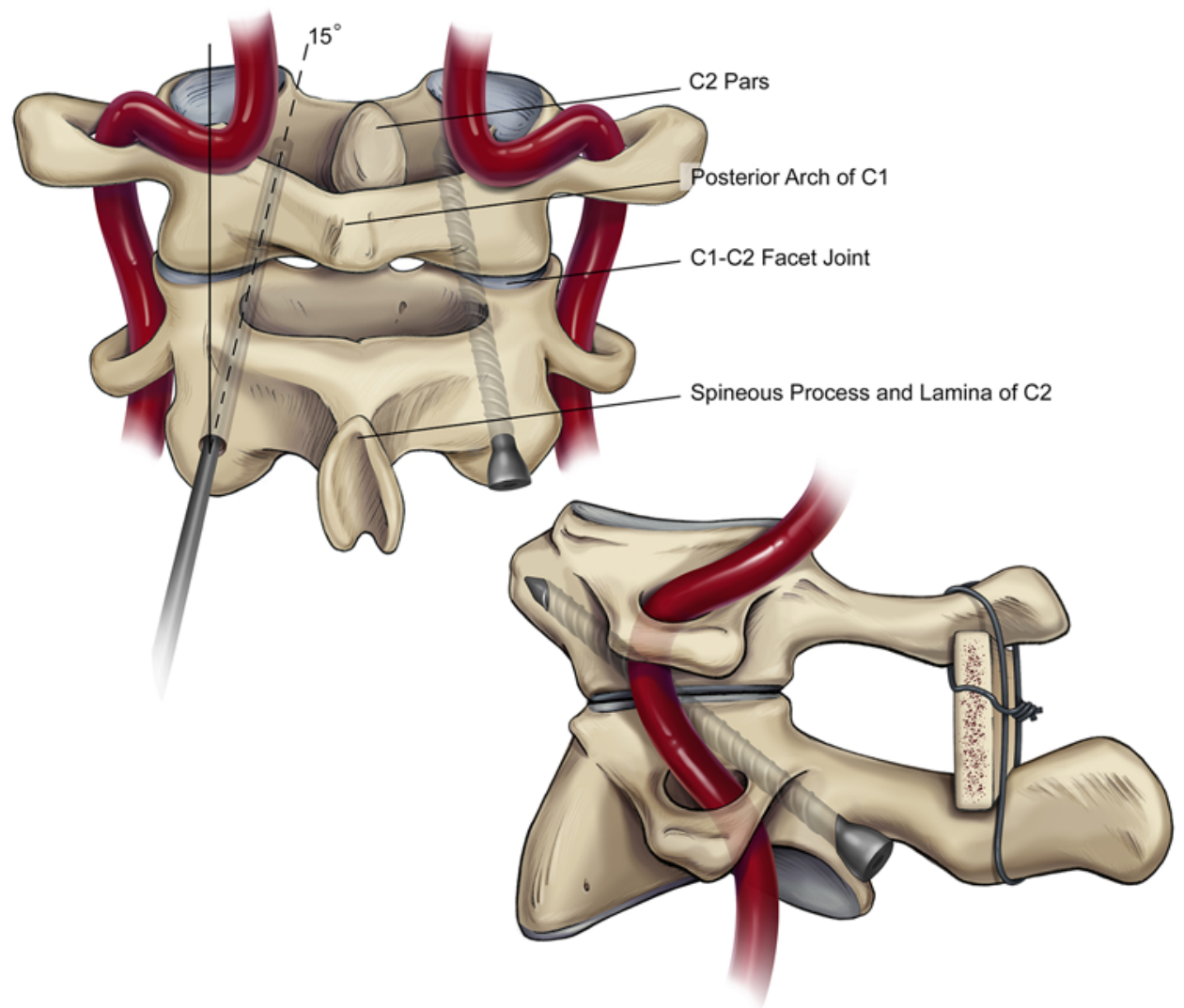

FIG. 2. C1-2 transarticular screw technique. Note the screw proximity to the vertebral arteries, making this a very challenging stabilization technique in children. Image created by Katherine Relyea, MS, CMI, and printed with permission from Baylor College of Medicine; first appeared in Chern JJ, et al: Instrumentation and stabilization of the pediatric spine: technical nuances and age-specific considerations, in Quinones-Hinojosa A (ed): Schmidek \& Sweet: Operative Neurosurgical Techniques: Indications, Methods, and Results, ed 6. Philadelphia: Elsevier Saunders, 2012, Vol 1, pp 759-767. Figure is available in color online only.

pedicle screw placement carries a smaller risk of vertebral artery injury than $\mathrm{C} 1-2$ transarticular screw placement. ${ }^{65}$ However, the risk to the vertebral arteries and spinal cord is still definable (Fig. 4). ${ }^{119}$

Wright ${ }^{160,161}$ described the translaminar screw technique (Fig. 5). Translaminar screw technique allows for safe, rigid fixation of $\mathrm{C} 2$ by circumventing the risk of vertebral artery injury. The literature demonstrates that this technique of crossing and noncrossing laminar screws is a safe and effective method of C2 fixation in children..$^{32,87,136}$ Although a recent meta-analysis of cadaver studies brought concern with the lateral bending stability in $\mathrm{C} 1$ lateral mass- $\mathrm{C} 2$ translaminar screws, the difference was not statistically significant. ${ }^{42}$ Based on reports in the literature of the small series of children and slightly larger patient series of adults in which $\mathrm{C} 2$ translaminar screws are used, the follow-up and fusion rate are quite satisfactory. ${ }^{138}$

\section{Subaxial Cervical Spine (C3-7)}

Lateral Mass Screws. Lateral mass screw fixation of the cervical spine has been shown to be effective in adult patients. ${ }^{36,124,134}$ There are 2 popular techniques for placing lateral mass screws. These are the Roy-Camille and Magerl techniques, both of which have been extrapolated to pediatric patients. The youngest patient reported who underwent successful lateral mass screw placement was 8.2 years old. ${ }^{9}$ This corresponds with the age in which the pediatric spine is expected to transform into its adult configuration..$^{12}$

Placing lateral mass screws in even younger children is feasible. However, surgery can be challenging because of proximity to the vertebral arteries, small bone volume in the lateral mass to safely accommodate a screw of sufficient width and length $(3.5 \times 14 \mathrm{~mm}),{ }^{134}$ and violation of the facet joint, which predisposes to untoward adjacentlevel changes., ${ }^{9,12,25}$ Often, the spine surgeon is allowed only one opportunity to accurately place a screw, as the small size of the lateral mass does not allow for multiple attempts. Furthermore, a shorter screw may need to be placed $(3.5 \times 10 \mathrm{~mm})$, compromising the strength of the construct. Our technique for placing subaxial lateral mass screws is illustrated in Fig. 6.

Sublaminar Wires. Sublaminar wires are considered "old school" but solid alternatives when lateral mass screws are not feasible. ${ }^{35,50,103,144,148}$ They are still frequently used in combination with contoured rods and/or lateral mass screws. It has been demonstrated that the wires confer immediate stability and help achieve solid fusion. In 

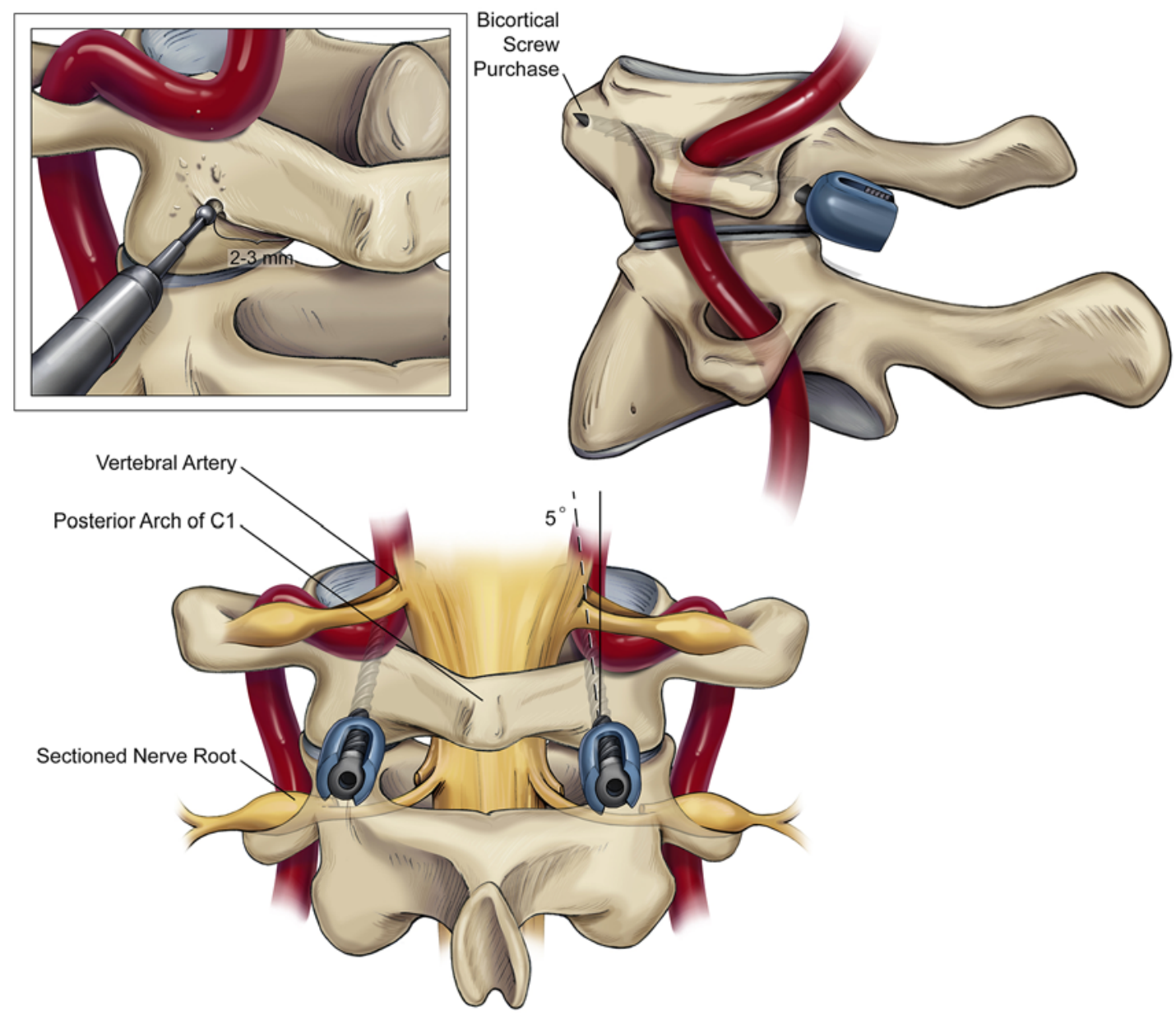

FIG. 3. $C 1$ lateral mass crew technique. The entry point of the $C 1$ lateral mass screw is deep at the confluence of the $C 1$ lamina and $\mathrm{C} 1$ lateral mass to avoid the vertebral artery in the more superficial sulcus arteriosus. The medial surface of the $\mathrm{C} 1$ lateral mass should be palpated as an important landmark. The entry point should be $2-3 \mathrm{~mm}$ from the medial aspect of the $\mathrm{C} 1$ lateral mass. The lateral aspect of the lateral mass should be avoided, as this is where the vertebral artery resides. Bicortical screw purchase is desired to increase pullout strength. To help with exposure of the bony landmarks for $\mathrm{C} 1$ lateral mass screw placement, we recommend sectioning the $\mathrm{C} 2$ nerve root. Judicious (and continuous) bipolar coagulation of the venous plexus surrounding the $\mathrm{C} 2$ nerve root should be performed. Stepwise division of the $\mathrm{C} 2$ nerve root proximal to the dorsal root ganglion. There is no reason to rush this portion of the procedure if acceptable blood loss is a goal of surgery. Image created by Katherine Relyea, MS, CMI, and printed with permission from Baylor College of Medicine; first appeared in Chern JJ, et al: Instrumentation and stabilization of the pediatric spine: technical nuances and age-specific considerations, in Quinones-Hinojosa A (ed): Schmidek \& Sweet: Operative Neurosurgical Techniques: Indications, Methods, and Results, ed 6. Philadelphia: Elsevier Saunders, 2012, Vol 1, pp 759-767. Figure is available in color online only.

a biomechanical study ${ }^{13}$ and systematic review ${ }^{155}$ comparing rigid constructs (screw-rod) and nonrigid constructs (screw-wire/wires only), screw-rod constructs outperform screw-wire/wire-only constructs in terms of instrumentation failure and fusion rates. Furthermore, our series of pediatric spine cases indicate that instrumentation of the cervical spine may carry a safer and more efficacious profile than a wire construct. ${ }^{66}$ The sublaminar wire method, nevertheless, remains a salvage method to obtain internal support for fusion. ${ }^{76,97,116}$

Pedicle Screws. Unlike in the thoracic and lumbar spine, subaxial cervical pedicle screws are not widely utilized because of the high risk to adjacent neurovascular structures involved in cannulating the cervical pedicles. ${ }^{21}$ Abumi et al., ${ }^{1,2}$ alone advocate for cervical pedicle screws, reported excellent clinical outcomes for use in the middle to lower cervical spine.

Translaminar Screws. Subaxial cervical translaminar screw placement is an option as a fixation point (Fig. 5). Theoretically, translaminar screws can be placed under direct vision, avoid important neurovascular structures, and attain a screw length much longer than a lateral mass screw. In reality, however, the laminar thickness of the subaxial cervical spine in a child can rarely accommodate a translaminar screw. ${ }^{33}$

\section{Thoracic and Lumbar Spine}

Wires, Hooks, and Pedicle Screws. Posterior thoracolumbar instrumentation has been traditionally divided into 


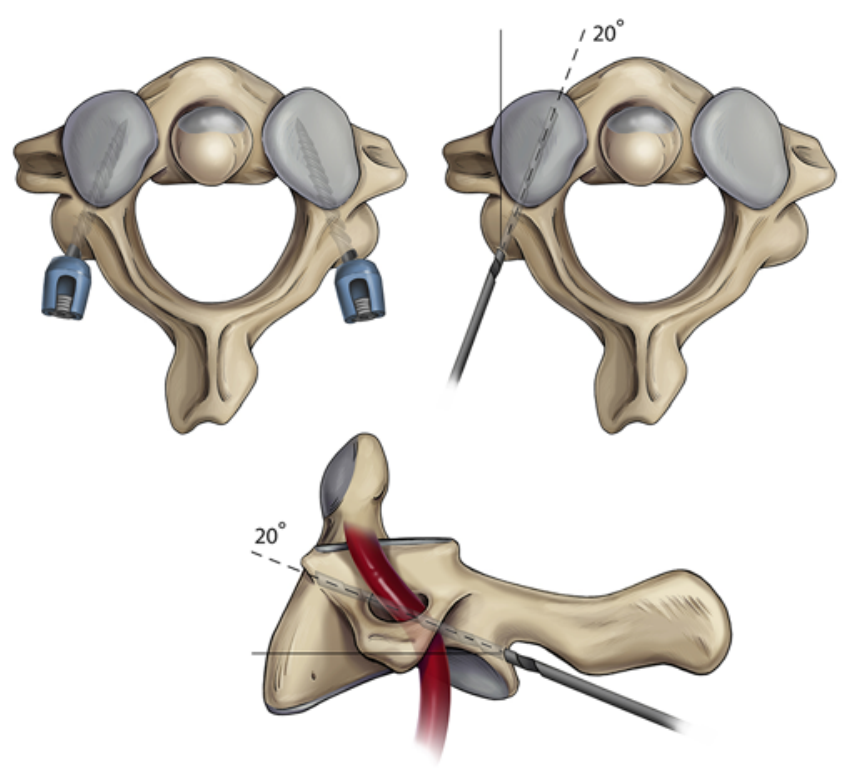

FIG. 4. C2 pars/pedicle screw technique. Note the proximity of the spinal canal and vertebral artery in comparison with the translaminar screw in Fig. 5. Image created by Katherine Relyea, MS, CMI, and printed with permission from Baylor College of Medicine; first appeared in Chern JJ, et al: Instrumentation and stabilization of the pediatric spine: technical nuances and age-specific considerations, in Quinones-Hinojosa A (ed): Schmidek \& Sweet: Operative Neurosurgical Techniques: Indications, Methods, and Results, ed 6. Philadelphia: Elsevier Saunders, 2012, Vol 1 , pp 759-767. Figure is available in color online only.

rigid and nonrigid constructs. The earliest arthrodesis constructs incorporated the spinous processes or other dorsal bony structures with structural autograft. ${ }^{28}$ Although simple wiring techniques are no longer used today, Luque wiring, which employs sublaminar wires as anchor points, is still used occasionally. The Luque instrumentation system was a step toward more rigid segmental spinal instrumentation, avoiding mandatory postoperative external orthoses. ${ }^{93}$ Wiring techniques are considered nonrigid because they allow "pistoning" of the spine in a craniocaudal direction.

The first hook-based system was the Harrington rod, which was introduced in the 1960s. ${ }^{137}$ These constructs were much more rigid than previous wiring techniques, leading to improved fusion rates that avoided the need for postoperative bracing. ${ }^{93}$ The disadvantage of these constructs, as with pedicle screw fixation, is the effect of fusion on adjacent segments. In contrast to the $3 \mathrm{D}$ fixation of pedicle screw constructs, hooks anchor to the posterior elements alone and do not have the same ability to correct severe scoliosis curves. ${ }^{85}$

Spinal instrumentation in the thoracic and lumbar spine has primarily been applied to the surgical reduction and fixation of spinal deformities. After the introduction of pedicle screws ${ }^{22}$ and advent of Harrington instrumentation, ${ }^{59}$ spinal internal pedicle screw fixation gained popularity in the operative treatment of traumatic and nontraumatic spine disorders. ${ }^{20,78,125,126}$ Pedicle screw fixation offer 3-column control of the spinal column with powerful correction in the axial, sagittal, and coronal planes (Fig. 7). When compared with nonrigid methods, such as hook-
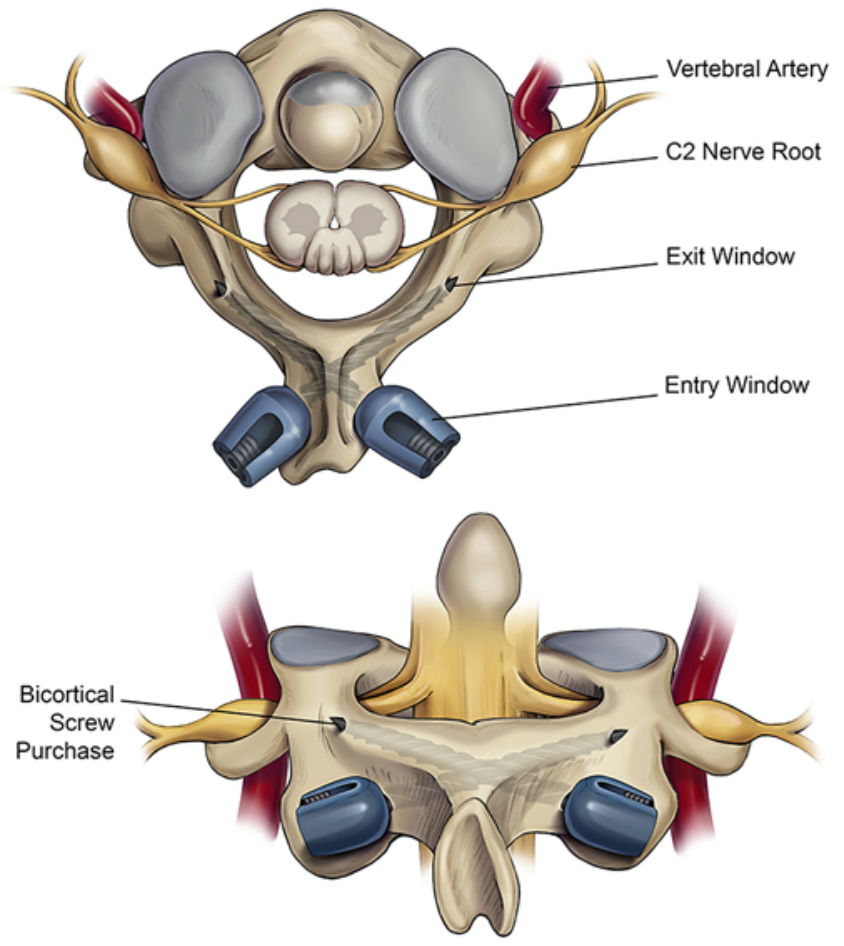

FIG. 5. Translaminar screw technique. C2 translaminar screw fixation is a safe technique for rigid fixation and avoids the vertebral arteries. A potential drawback to this technique is breach of the nonvisualized ventral laminar wall leading to dural laceration, CSF leak, or spinal cord injury. Wright's method for placing laminar screws can be modified with a small exit window in the dorsal cortex of the lamina at the laminofacet line. This exit window allows the surgeon to visualize the tip of the screw to ensure that it has not penetrated the ventral laminar cortex. Careful study of the preoperative CT scan can indicate screw length and width. Image created by Katherine Relyea, MS, CMI, and printed with permission from Baylor College of Medicine; first appeared in Chern $\mathrm{JJ}$, et al: Instrumentation and stabilization of the pediatric spine: technical nuances and age-specific considerations, in Quinones-Hinojosa A (ed): Schmidek \& Sweet: Operative Neurosurgical Techniques: Indications, Methods, and Results, ed 6. Philadelphia: Elsevier Saunders, 2012, Vol 1 , pp 759-767. Figure is available in color online only.

and-wire constructs, pedicle screw constructs have higher fusion rates, lower implant failures, and obviate the need for postoperative bracing. ${ }^{14,90,91,143}$

Polyester Bands. Polyester bands with a locking mechanism to the rod are a relatively new innovation. They serve as an alternative to traditional anchors, such as wire, hooks, and screws. Polyester is a biologically inert material with favorable mechanical properties, such as high tensile strength, high resistance to stretch, wet or dry, and resistance to degradation. ${ }^{133}$ It represents an excellent candidate material for use in the spine. As an example, polyester has been incorporated in spinal constructs in Europe for more than 20 years (K. Mazda, personal communication, October 17, 2007).

The gentleness and flexibility of polyester seem to make it ideal for implantation in the pediatric spine. It is particularly useful when anatomy precludes safe placement of hooks or screws despite the availability of image guidance. Like other anchors to the spine, these polyester bands 


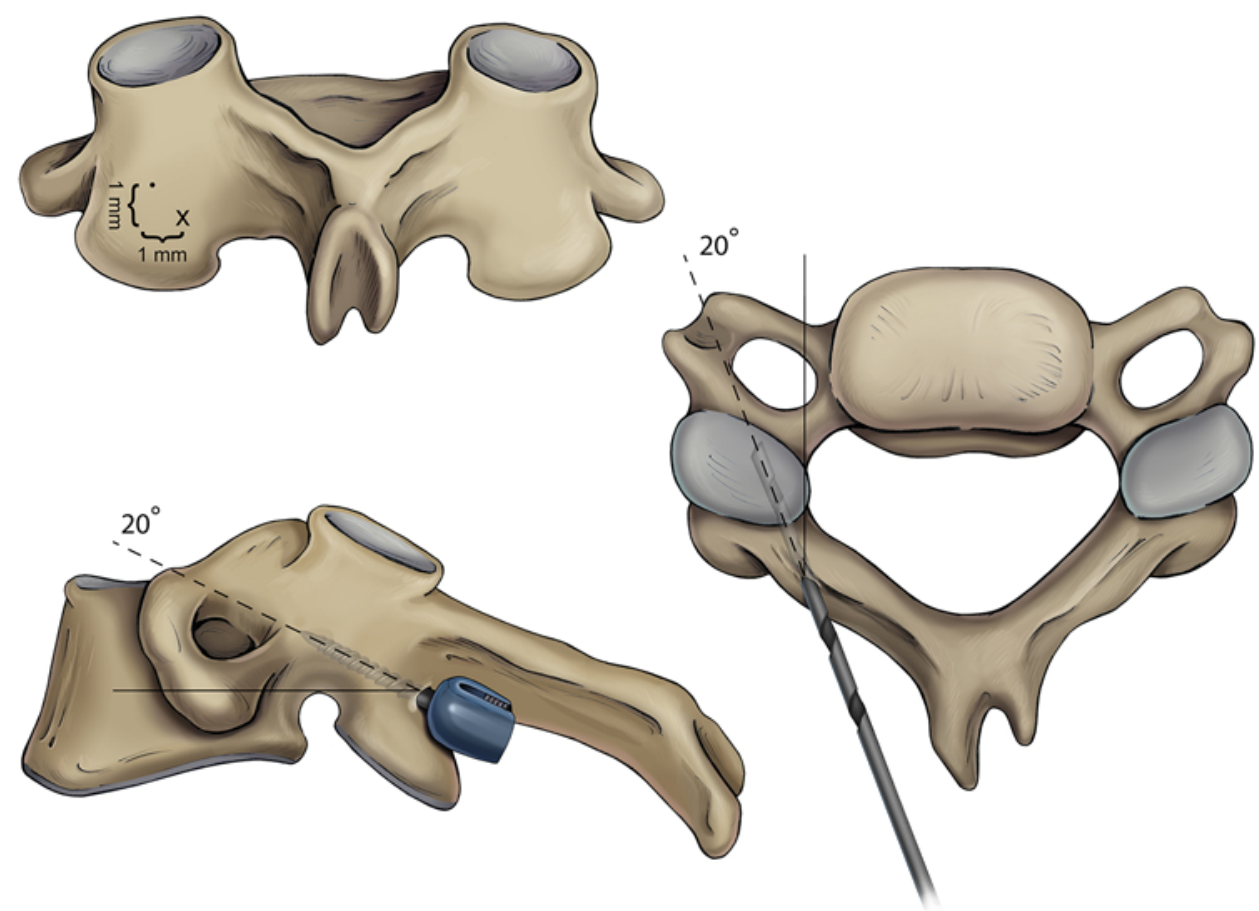

FIG. 6. C3-7 lateral mass screw technique. The entire lateral mass of the subaxial cervical spine should be exposed at each level. On the dorsal square face of the lateral mass, an entry point $1 \mathrm{~mm}$ medial and $1 \mathrm{~mm}$ caudal from the midpoint (dot) should be selected. The drill and screw trajectory should be directed "up and out" toward the deep superior and ventral corner of the lateral mass box (about $20^{\circ}$ lateral and $20^{\circ}$ rostral) to avoid vertebral artery and nerve root injury, respectively. Image created by Katherine Relyea, MS, CMI, and printed with permission from Baylor College of Medicine; first appeared in Chern JJ, et al: Instrumentation and stabilization of the pediatric spine: technical nuances and age-specific considerations, in Quinones-Hinojosa A (ed): Schmidek \& Sweet: Operative Neurosurgical Techniques: Indications, Methods, and Results, ed 6. Philadelphia: Elsevier Saunders, 2012, Vol 1, pp 759-767. Figure is available in color online only.

along with their rod-locking mechanism may be used to attain segmental control, reduction, and fusion (Fig. 8). Like other forms of sublaminar spinal instrumentation, such as sublaminar wire or laminar hooks, sublaminar polyester bands have a higher risk of spinal cord injury than pedicle screws. ${ }^{15,29,51,62,72,92,141}$ The intracanalicular space is violated with each pass of the sublaminar polyester band, whereas the intention of pedicle screws is to stay intraosseous and outside the spinal canal. The learning curve for placing sublaminar polyester bands is comparatively shorter than for placing pedicle screws; nonetheless, meticulous technique is necessary to reduce the risk of spinal cord injury, especially in the thoracic and thoracolumbar spine.

Complications may also occur with over-tensioning of the polyester bands, causing them to fracture through osteoporotic or partially cartilaginous bone, which was encountered in our early experience with these bands. Aggressive decortication of the lamina and subsequent decrease in laminar strength may also predispose it to fracture. ${ }^{11}$ Promising results have been demonstrated with hybrid spinal constructs incorporating sublaminar polyester bands; however, long-term evaluations are still needed. ${ }^{38,142}$

\section{Complications and Complication-Avoidance Strategies}

There were no deaths attributable to spinal instrumentation placement in our series of children. However, other complications included hardware-related skin breakdown $(1.8 \%)$, infection $(1.8 \%)$, proximal junctional kyphosis $(1.0 \%)$, pseudarthrosis $(1.0 \%)$, screw malpositioning $(0.5 \%)$, cerebrospinal fluid leak $(0.5 \%)$, hardware failure $(0.5 \%)$, graft migration $(0.3 \%)$, nerve root injury $(0.3 \%)$, and vertebral artery injury $(0.3 \%)$. Our avoidance strategies for each of these complications are detailed in Table 2.

\section{Discussion}

\section{History of Spinal Instrumentation in Children}

The history of spinal instrumentation in children begins with the treatment of scoliosis by luminaries in spine surgery, including Dr. Russell A. Hibbs, Dr. Fred H. Albee, and Dr. H. P. H. Galloway. ${ }^{37}$

The greatest breakthrough for the operative treatment of scoliosis came with the advent of the Harrington rod. Dr. Harrington started practice in Houston, Texas, in 1945 at Jefferson Hospital. During this time, he took a special interest in children with poliomyelitis and the high incidence of neuromuscular scoliosis in this patient population. ${ }^{37,58}$ Dr. Harrington quickly realized at the time that the therapies used to treat idiopathic scoliosis-physical therapy, bracing, casting, and early surgical techniqueswere not appropriate for poliomyelitis patients. The Harrington rod was born out of his curiosity and compassion 


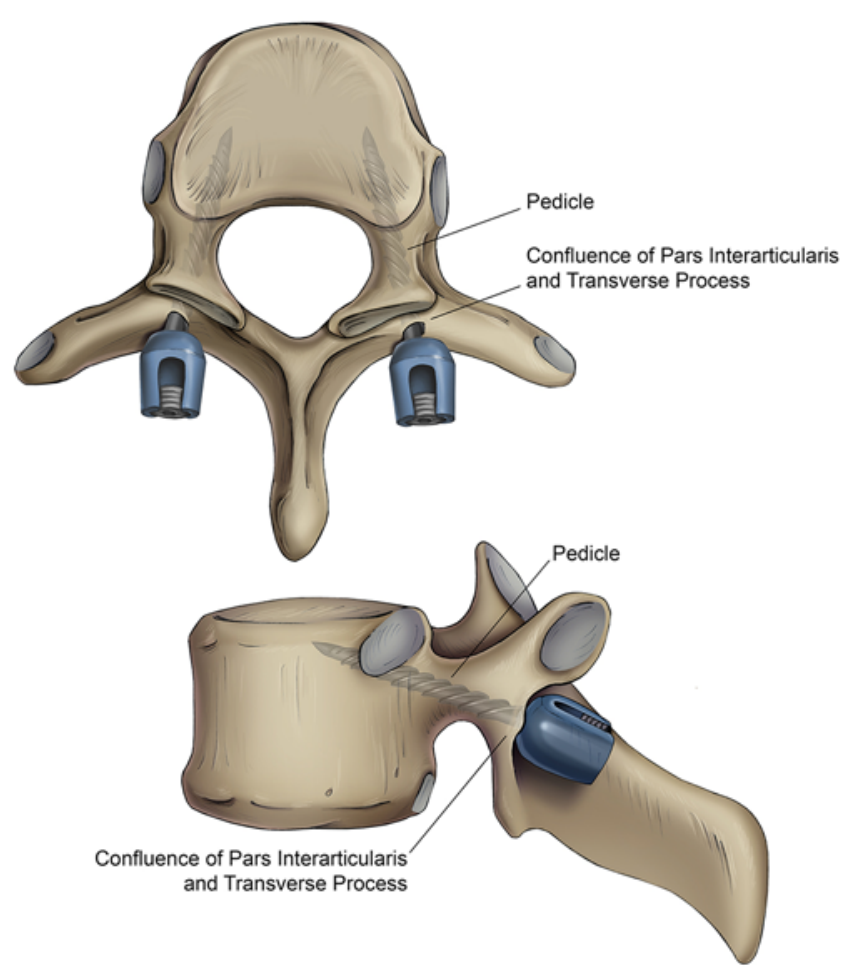

FIG. 7. Thoracic and lumbar pedicle screw technique. Pedicle screw placement may start at the confluence of the pars interarticularis and transverse process. Rostral-caudal and mediolateral angulation of the pedicles should be studied prior to surgery at each vertebral level to help guide screw trajectory. There may be a role for intraoperative image guidance in the placement of pedicle screws. Image created by Katherine Relyea, MS, CMI, and printed with permission from Baylor College of Medicine; first appeared in Chern JJ, et al: Instrumentation and stabilization of the pediatric spine: technical nuances and age-specific considerations, in Quinones-Hinojosa A (ed): Schmidek \& Sweet: Operative Neurosurgical Techniques: Indications, Methods, and Results, ed 6. Philadelphia: Elsevier Saunders, 2012, Vol 1, pp 759-767. Figure is available in color online only.

for patients; it was the first iteration of an implantable spinal instrumentation system. ${ }^{37}$

After the Harrington rod system, many other notable systems, such as the Luque instrumentation system in $1977^{93}$ and the Cotrel-Dubousset system in 1978, were created utilizing the contemporary spine surgery knowledge and techniques for deformity correction. This trend in development of spinal instrumentation represented a slow march toward 3D control and 3-column fixation of the spinal column, the standard for spinal instrumentation systems today. ${ }^{10,120,121,151}$

\section{Anterior Spinal Instrumentation}

Anterior approaches to the spinal column for the placement of instrumentation are infrequent compared with posterior approaches. Anterior spinal instrumentation is most commonly confined to the cervical spine. Case series on anterior spine instrumentation have recently been reported. ${ }^{48}$

\section{Advantages of Anterior Instrumentation}

There are several important advantages to anterior ap- proaches over posterior approaches. The patient does not need to be turned prone for positioning on the operating room table, which is important when the spinal column is unstable. Anterior spinal instrumentation may allow for less extensive fusion (i.e., motion segments spared), may require less soft-tissue dissection to expose the spine, may be associated with decreased blood loss, and may have higher fusion rates and lower infection rates. ${ }^{16,44,95,147,149,154}$ In the growing spine, addition of anterior instrumentation to a previous posterior fusion construct (circumferential fusion) may help prevent the occurrence of "crankshaft" deformity. ${ }^{41,82,140}$

\section{Disadvantages of Anterior Instrumentation}

The most significant disadvantage of anterior spinal instrumentation is that it is rarely a stand-alone construct. A second procedure may be required to place supplemental posterior spinal instrumentation. Contemporary posterior or posterolateral approaches to the spine (e.g., costotransversectomy and lateral extracavitary) may allow simultaneous exposure of the anterior, middle, and posterior columns of the spine. ${ }^{118}$ In these approaches, anterior and posterior spinal instrumentation may be inserted through a single approach.

\section{Biomaterials}

Autograft, including iliac crest, tibia/fibula, and rib, remains the gold standard in pediatric spine surgery. However, the materials may also be primarily cartilaginous in young children, thereby limiting its use as structural autograft. Titanium and polyetheretherketone (PEEK) cages ${ }^{79}$ have been used as vehicles to hold graft material while providing immediate load-bearing properties. ${ }^{6,30,31,86}$ Due to the favorable modulus of elasticity of PEEK in comparison with bone, it is preferred over titanium cages. ${ }^{159}$ Titanium cage use is reserved for older children and adolescents with higher density bone; ${ }^{6}$ otherwise, titanium cages are prone to settle and telescope.

The off-label use of bone morphogenetic protein (BMP) has increased in both the adult and pediatric patient populations since its approval by the FDA in 2002. ${ }^{67}$ Allograft, in combination with BMP, may provide high fusion rates that rival that of the autograft gold standard. In younger children where the quantity of autograft is limited, BMP offers a promising alternative. Other purported advantages of BMP include decreased operative time, lower blood loss, and elimination of donor site morbidity. The safety and efficacy of BMP has been documented in adult and pediatric case reports and case series..$^{64,130-132}$ Reported complications of BMP include seroma formation, softtissue swelling, delayed wound healing, and heterotopic bone formation. The long-term effects of BMP, such as oncogenesis, are unknown. Therefore, full informed consent from patients and their parents for the cautious use of BMP should be obtained.

\section{Intraoperative Spinal Navigation}

The use of intraoperative spinal navigation for screw insertion has been shown to improve accuracy and decrease unexpected returns to the operating room for screw revi- 


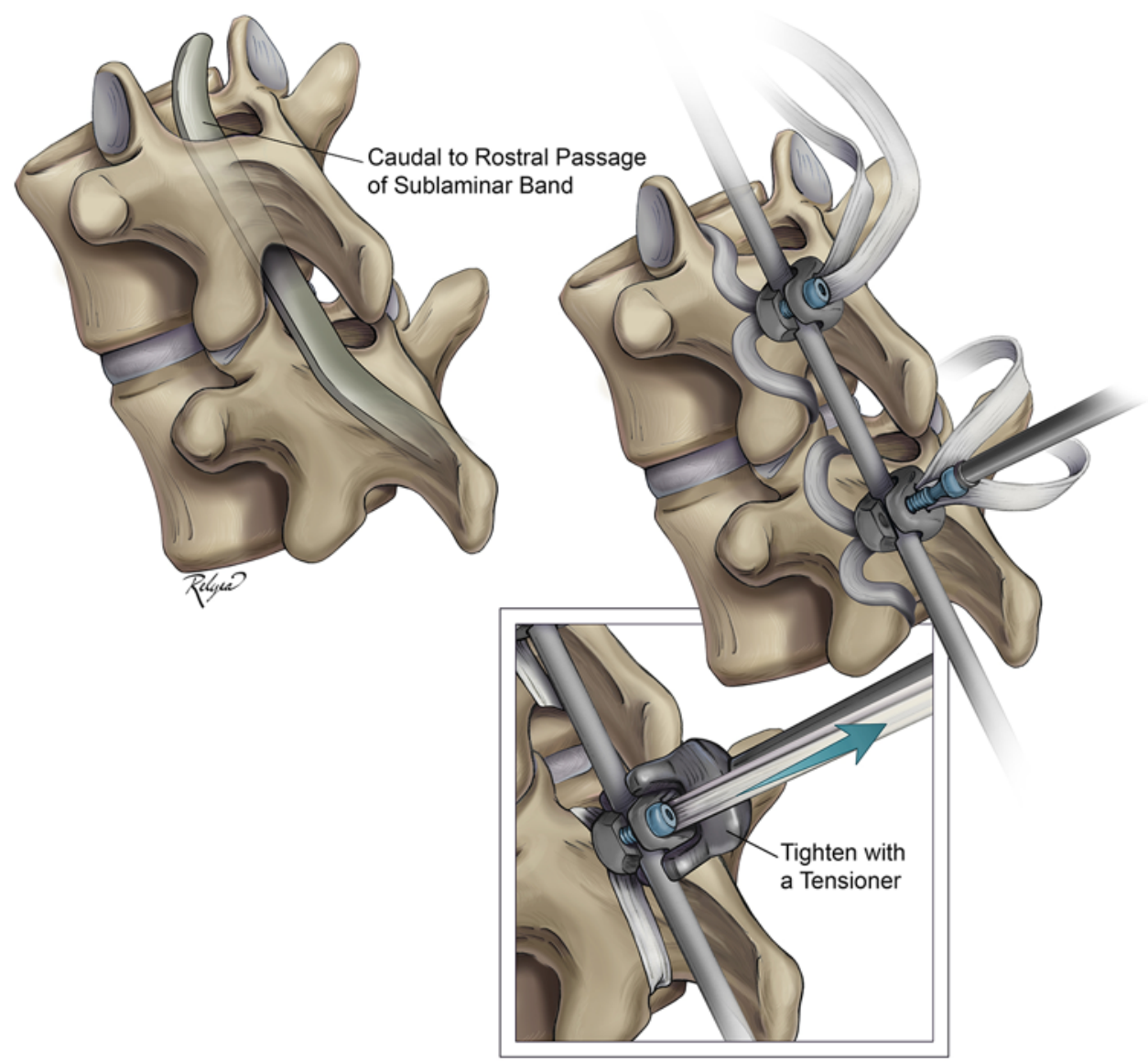

FIG. 8. Sublaminar wire/band technique. The ligamentum flavum is resected in the interlaminar spaces above and below the lamina of interest. We are careful not to resect too much of the lamina itself. A gentle curve for the malleable semirigid tip of the wire or polyester band is created. The tip is passed gently underneath the lamina from caudal to rostral. A hemostat or nerve hook is used to snare the tip of the wire or polyester band. Through use of a push-pull technique to avoid a loop of wire or band compressing the thecal sac and spinal cord, the wire or band is progressively passed underneath the lamina until the semirigid tip has fully traversed the lamina. Once all sublaminar wires or bands have been passed, each wire or band is secured to the rod. Sequential tensioning may then be applied to produce a translation of the spine toward the rod. Image created by Katherine Relyea, MS, CMI, and printed with permission from Baylor College of Medicine; first appeared in Chern JJ, et al: Instrumentation and stabilization of the pediatric spine: technical nuances and age-specific considerations, in Quinones-Hinojosa A (ed): Schmidek \& Sweet: Operative Neurosurgical Techniques: Indications, Methods, and Results, ed 6. Philadelphia: Elsevier Saunders, 2012, Vol 1, pp 759-767. Figure is available in color online only.

sion. 7,73,96,102,104,115,150 The use of computerized image guidance in the pediatric spine seems even more opportune as there is a smaller margin for error in placing spinal instrumentation. Most of the pediatric spine literature ${ }^{82,83,117}$ has confirmed that intraoperative spinal navigation results in a low rate of misplaced screws and related reoperations.

A potential criticism of intraoperative spinal navigation is the radiation exposure during intraoperative CT scanning, especially in the pediatric population. ${ }^{75,122}$ There are numerous studies that correlate early exposure to radiation in pediatric populations to long-term increased cancer risk. ${ }^{3,24,74}$ More long-term studies are necessary to assess long-term cancer risk in pediatric patients undergoing spinal instrumentation.

\section{Long-Term Consequences of Fusion in a Growing Spine}

A major difference between the pediatric spine and adult spine is the potential for continued growth from childhood to adolescence. ${ }^{71}$ This growth must be factored into any decision of performing a long-segment fusion in a child. Adverse iatrogenic effects from spinal fusion include limitation of range of motion, stunting future growth, development of secondary deformity (e.g., crankshaft deformity), and adjacent-level disease..$^{60,156-158}$

Because there are no epiphyseal growth plates between the occiput and $\mathrm{C} 2$, it is not unexpected that several studies have shown minimal effect of vertical growth restriction across an occipitocervical fusion. ${ }^{5,8,12,52,74,98,113,146,152} \mathrm{~A}$ dedicated study analyzing spinal alignment and growth in children after subaxial cervical fusion demonstrated that there are continued dynamic changes across the fused segments. ${ }^{54}$ The authors showed $79 \%, 83 \%$, and $100 \%$ of expected growth across 4-level, 3-level, and 2-level fusions, respectively. Overall, $62 \%$ of patients with 24 months of follow-up showed growth across the fusion construct. Crankshaft deformity occurs when posterior fusion is 
TABLE 2. Complications and avoidance strategies

\begin{tabular}{|c|c|}
\hline Complications & Avoidance Strategies \\
\hline $\begin{array}{l}\text { Hardware-related } \\
\text { skin breakdown }\end{array}$ & $\begin{array}{l}\text { - Counter-sinking lower-profile spinal instrumentation to ensure no local prominence } \\
\text { - Periop consultation \& collaboration w/ plastic surgery to discuss need for soft-tissue flaps \&/or expanders } \\
\text { - Consultation to optimize nutritional status prior to surgery }\end{array}$ \\
\hline Infection & $\begin{array}{l}\text { - Preop nutrition consultation to control preop hyperglycemia \& weight loss prior to surgery; remembering that an obese patient } \\
\text { can still be malnourished } \\
\text { - Following a standardized complex spine infection prevention protocol, including preop skin antisepsis w/ chlorhexidine surgical } \\
\text { scrubs; use of adapted antimicrobial prophylaxis protocols w/ preincision cefazolin; intraop pulse irrigation w/ antibiotic solu- } \\
\text { tion \& intraop topical vancomycin powder }\end{array}$ \\
\hline $\begin{array}{l}\text { Proximal junctional } \\
\text { kyphosis/pseud- } \\
\text { arthrosis }\end{array}$ & $\begin{array}{l}\text { - Decreasing rigidity at the top of long-segment constructs by placement of hooks rather than pedicle screws to provide a transi- } \\
\text { tion to the noninstrumented spine } \\
\text { - Bending kyphosis into the rods at the rostral end of the spinal construct } \\
\text { - Using rods that are less stiff, such as titanium alloy or cobalt-chrome, rather than stainless steel }\end{array}$ \\
\hline $\begin{array}{l}\text { Screw malposition- } \\
\text { ing }\end{array}$ & $\begin{array}{l}\text { - Use of intraop computerized image-guided screw insertion techniques } \\
\text { - Intraop CT to check postinsertion screw placement } \\
\text { - Careful attention to trajectory \& anatomical landmarks during screw placement, even when using adjuncts like image guidance }\end{array}$ \\
\hline CSF leak & $\begin{array}{l}\text { - Awareness of anatomical anomalies or bony defects on preop imaging } \\
\text { - Meticulous attention to development of surgical planes between the dura \& overlying bone or soft tissue during decompression } \\
\text { procedures } \\
\text { - Use of eggshell technique during use of the high-speed air-powered drill } \\
\text { - Employing the surgical assistant to protect the dura while working close to it }\end{array}$ \\
\hline Hardware failure & $\begin{array}{l}\text { - Careful attention to spinal alignment during deformity correction-avoidance of over- or under-correction } \\
\text { - Achieving a well-balanced spine will place less stress on the rods } \\
\text { - Considering "outriggers" or a 4-rod construct that spans 3-column osteotomy sites or irreducible unbalanced spinal deformities }\end{array}$ \\
\hline $\begin{array}{l}\text { Nerve root/vertebral } \\
\text { artery injury }\end{array}$ & $\begin{array}{l}\text { - Careful study of preoperative imaging, such as CTA \&/or MRI, particularly in cases of congenital anomalies of the spine at the } \\
\text { craniocervical junction }\end{array}$ \\
\hline
\end{tabular}

achieved yet unrestricted growth continues in the anterior column of a young child. ${ }^{43,61,84}$ The posterior fusion mass then acts as a tether and center of rotation causing progressive angulation and lordosis. As mentioned previously, completion of a circumferential fusion (i.e., addition of an anterior fusion) may arrest crankshaft deformity. ${ }^{41,81}$ However, this possible solution for crankshaft deformity is controversial, debated, and being studied. ${ }^{26,129}$

Long-segment thoracic fusion should be avoided in children younger than 8 years, as alveolar and lung development occurs until the age of 8 years. ${ }^{40}$ Fusion of the spine while lung maturity is occurring can result in restrictive lung disease and subsequent pulmonary hypertension. Pulmonary hypertension can lead to right heart failure and iatrogenic death - a complication from inappropriate fusion across the thoracic spine and rib cage.

Adjacent-level disease is defined as premature degeneration of supra- or subjacent levels to fusion. The fused segment is spared biomechanical force, but this excess force is distributed to the next mobile segments above and below. The rate of development of adjacent-level disease during the first 10 years after anterior cervical discectomy and fusion is estimated to be $2.9 \%$ per year in adult studies. In the adult lumbar spine, the rate of adjacent-level disease is estimated to be $3.6 \%$ per year. ${ }^{49}$ To our knowledge, the rate of adjacent-segment degeneration in children has not been assessed. Logically, children should carry a much greater risk of adjacent-segment degeneration given a much longer life expectancy. Further studies are needed to elucidate this risk.

\section{Fusionless Spine Surgery}

The future of spine surgery in children may lie in the continued refinement of fusionless techniques to allow growth and preserve motion. Growing rod constructs, such as traditional growing rods, the Shilla technique, vertical expandable prosthetic titanium rib (VEPTR, DePuy Synthes), and magnetic expansion control (MAGEC, NuVasive) rods, have been used to address early-onset scoliosis..$^{27,70,99}$ However, these techniques are plagued with complications and unexpected outcomes, including wound breakdown, infection, premature auto-fusion, and device failure. . $^{1780,89,153}$

Vertebral body growth modulation is a new and exciting area in the field of fusionless deformity surgery. Progression of skeletal deformity during growth is thought to be governed by the Hueter-Volkmann law. ${ }^{100}$ This law states that growth depends on the amount of compression on the growth plate. Increased compression retards growth, while decreased compression accelerates growth. If this principle is applied to the growing child with scoliosis, then the concave portion of the scoliotic spine will have increased loading on the vertebral body growth plate-retarding growth-and the convex portion of the curve will have decreased loading-increasing growth-leading to an overall vicious cycle of curve progression. Various skeletal fixation devices have been successfully used in animal models to correct induced scoliosis curves. . $^{23,101,105,107,108}$

Based on the above principles, vertebral body stapling and vertebral body tethering were developed. The results 
with each technique appear to be promising. Vertebral body stapling involves placing unilateral disc-sparing staples on the convex side of a scoliotic curve to increase compression on the growth plate and reduce overall growth. ${ }^{18,19,128}$

There is mounting evidence that intricate underlying genetic abnormalities contribute to the 3D structural deformities found in scoliosis. Prior studies have identified candidate genes associated with adolescent idiopathic scoliosis, such as GPR126, ${ }^{77}$ BNC $2,{ }^{111}$ PAX $1,{ }^{135}$ LBXIasl, ${ }^{163}$ $P O C 5,114$ and $A K A P 2 .{ }^{88}$ More recently, MapK7 was shown to be associated with severe spinal deformity and a defective osteogenesis phenotype in idiopathic scoliosis. ${ }^{162}$ Understanding the molecular underpinnings that generate spinal deformities may allow for early targeted therapy based on a child's underlying genetic profile. The development and refinement of new fusionless surgical techniques may allow for early treatment of pediatric patients with high risk of deformity progression without the long-term consequences of current fusion constructs.

\section{Conclusions}

Pediatric neurosurgeons with an interest in complex spine disorders in children should develop a comprehensive armamentarium of safe techniques for placing rigid and nonrigid spinal instrumentation even in the smallest of children, with low complication rates. The present review provides some benchmarks and outcomes for comparison, and furnishes a historical perspective of the past and future of pediatric spine surgery.

\section{Acknowledgments}

In memory of Dr. Sanjiv Bhatia.

\section{References}

1. Abumi K, Itoh H, Taneichi H, Kaneda K: Transpedicular screw fixation for traumatic lesions of the middle and lower cervical spine: description of the techniques and preliminary report. J Spinal Disord 7:19-28, 1994

2. Abumi K, Kaneda K: Pedicle screw fixation for nontraumatic lesions of the cervical spine. Spine (Phila Pa 1976) 22: $1853-1863,1997$

3. Acharya S, Sarafoglou K, LaQuaglia M, Lindsley S, Gerald W, Wollner N, et al: Thyroid neoplasms after therapeutic radiation for malignancies during childhood or adolescence. Cancer 97:2397-2403, 2003

4. Adeloye A, Kattan KR, Silverman FN: Thickness of the normal skull in the American blacks and whites. Am J Phys Anthropol 43:23-30, 1975

5. Ahmed R, Traynelis VC, Menezes AH: Fusions at the craniovertebral junction. Childs Nerv Syst 24:1209-1224, 2008

6. Akamaru T, Kawahara N, Tsuchiya H, Kobayashi T, Murakami H, Tomita K: Healing of autologous bone in a titanium mesh cage used in anterior column reconstruction after total spondylectomy. Spine (Phila Pa 1976) 27:E329E333, 2002

7. Amiot LP, Lang K, Putzier M, Zippel H, Labelle H: Comparative results between conventional and computerassisted pedicle screw installation in the thoracic, lumbar, and sacral spine. Spine (Phila Pa 1976) 25:606-614, 2000

8. Anderson RC, Kan P, Gluf WM, Brockmeyer DL: Longterm maintenance of cervical alignment after occipitocervical and atlantoaxial screw fixation in young children. $\mathbf{J}$ Neurosurg 105 (1 Suppl):55-61, 2006
9. Anderson RC, Ragel BT, Mocco J, Bohman LE, Brockmeyer DL: Selection of a rigid internal fixation construct for stabilization at the craniovertebral junction in pediatric patients. J Neurosurg 107 (1 Suppl):36-42, 2007

10. Asher M, Lai SM, Burton D, Manna B, Cooper A: Safety and efficacy of Isola instrumentation and arthrodesis for adolescent idiopathic scoliosis: two- to 12-year follow-up. Spine (Phila Pa 1976) 29:2013-2023, 2004

11. Aydingoz O, Bilsel N, Botanlioglu H, Bozdag E, Sunbuloglu E, Kesmezacar H: Effect of decortication on laminar strength during sublaminar wiring: an experimental study. J Spinal Disord Tech 17:498-504, 2004

12. Bailey DK: The normal cervical spine in infants and children. Radiology 59:712-719, 1952

13. Bambakidis NC, Feiz-Erfan I, Horn EM, Gonzalez LF, Baek S, Yüksel KZ, et al: Biomechanical comparison of occipitoatlantal screw fixation techniques. J Neurosurg Spine 8: 143-152, 2008

14. Belmont PJ Jr, Klemme WR, Dhawan A, Polly DW Jr: In vivo accuracy of thoracic pedicle screws. Spine (Phila Pa 1976) 26:2340-2346, 2001

15. Ben-David B: Spinal cord monitoring. Orthop Clin North Am 19:427-448, 1988

16. Bernstein RM, Hall JE: Solid rod short segment anterior fusion in thoracolumbar scoliosis. J Pediatr Orthop B 7:124-131, 1998

17. Bess S, Akbarnia BA, Thompson GH, Sponseller PD, Shah SA, El Sebaie H, et al: Complications of growing-rod treatment for early-onset scoliosis: analysis of one hundred and forty patients. J Bone Joint Surg Am 92:2533-2543, 2010

18. Betz RR, Kim J, D’Andrea LP, Mulcahey MJ, Balsara RK, Clements DH: An innovative technique of vertebral body stapling for the treatment of patients with adolescent idiopathic scoliosis: a feasibility, safety, and utility study. Spine (Phila Pa 1976) 28:S255-S265, 2003

19. Betz RR, Ranade A, Samdani AF, Chafetz R, D'Andrea LP, Gaughan JP, et al: Vertebral body stapling: a fusionless treatment option for a growing child with moderate idiopathic scoliosis. Spine (Phila Pa 1976) 35:169-176, 2010

20. Boos N, Webb JK: Pedicle screw fixation in spinal disorders: a European view. Eur Spine J 6:2-18, 1997

21. Borne GM, Bedou GL, Pinaudeau M: Treatment of pedicular fractures of the axis. A clinical study and screw fixation technique. J Neurosurg 60:88-93, 1984

22. Boucher HH: A method of spinal fusion. J Bone Joint Surg Br 41-B:248-259, 1959

23. Braun JT, Hoffman M, Akyuz E, Ogilvie JW, Brodke DS, Bachus KN: Mechanical modulation of vertebral growth in the fusionless treatment of progressive scoliosis in an experimental model. Spine (Phila Pa 1976) 31:1314-1320, 2006

24. Brenner D, Elliston C, Hall E, Berdon W: Estimated risks of radiation-induced fatal cancer from pediatric CT. AJR Am J Roentgenol 176:289-296, 2001

25. Brockmeyer DL, York JE, Apfelbaum RI: Anatomical suitability of C1-2 transarticular screw placement in pediatric patients. J Neurosurg 92 (1 Suppl):7-11, 2000

26. Burton DC, Asher MA, Lai SM: Scoliosis correction maintenance in skeletally immature patients with idiopathic scoliosis. Is anterior fusion really necessary? Spine (Phila Pa 1976) 25:61-68, 2000

27. Campbell RM Jr: VEPTR: past experience and the future of VEPTR principles. Eur Spine J 22 (Suppl 2):S106-S117, 2013

28. Capen DA, Garland DE, Waters RL: Surgical stabilization of the cervical spine. A comparative analysis of anterior and posterior spine fusions. Clin Orthop Relat Res (196):229_ 237, 1985

29. Carlioz H, Ouaknine M: [Neurologic complications of 
surgery of the spine in children.] Chirurgie 120:26-30, 1994-1995 (Fr)

30. Casey AT, Hayward RD, Harkness WF, Crockard HA: The use of autologous skull bone grafts for posterior fusion of the upper cervical spine in children. Spine (Phila Pa 1976) 20:2217-2220, 1995

31. Chadduck WM, Boop FA: Use of full-thickness calvarial bone grafts for cervical spinal fusions in pediatric patients. Pediatr Neurosurg 20:107-112, 1994

32. Chamoun RB, Relyea KM, Johnson KK, Whitehead WE, Curry DJ, Luerssen TG, et al: Use of axial and subaxial translaminar screw fixation in the management of upper cervical spinal instability in a series of 7 children. Neurosurgery 64:734-739, 2009

33. Chern JJ, Chamoun RB, Whitehead WE, Curry DJ, Luerssen TG, Jea A: Computed tomography morphometric analysis for axial and subaxial translaminar screw placement in the pediatric cervical spine. J Neurosurg Pediatr 3:121-128, 2009

34. Chern JJ, Relyea K, Jea A: Instrumentation and stabilization of the pediatric spine: technical nuances and age-specific considerations, in Quinones-Hinojosa A (ed): Schmidek \& Sweet: Operative Neurosurgical Techniques: Indications, Methods, and Results, ed 6. Philadelphia: Elsevier Saunders, 2012, Vol 1, pp 759-767

35. Coe JD, Warden KE, Sutterlin CE III, McAfee PC: Biomechanical evaluation of cervical spinal stabilization methods in a human cadaveric model. Spine (Phila Pa 1976) 14:1122-1131, 1989

36. Deen HG, Birch BD, Wharen RE, Reimer R: Lateral mass screw-rod fixation of the cervical spine: a prospective clinical series with 1-year follow-up. Spine J 3:489-495, 2003

37. Desai SK, Brayton A, Chua VB, Luerssen TG, Jea A: The lasting legacy of Paul Randall Harrington to pediatric spine surgery: historical vignette. J Neurosurg Spine 18:170177, 2013

38. Desai SK, Sayama C, Vener D, Brayton A, Briceño V, Luerssen TG, et al: The feasibility and safety of using sublaminar polyester bands in hybrid spinal constructs in children and transitional adults for neuromuscular scoliosis. J Neurosurg Pediatr 15:328-337, 2015

39. Dickman CA, Sonntag VK: Posterior C1-C2 transarticular screw fixation for atlantoaxial arthrodesis. Neurosurgery 43:275-281, 1998

40. DiFiore JW, Wilson JM: Lung development. Semin Pediatr Surg 3:221-232, 1994

41. Dohin B, Dubousset JF: Prevention of the crankshaft phenomenon with anterior spinal epiphysiodesis in surgical treatment of severe scoliosis of the younger patient. Eur Spine J 3: 165-168, 1994

42. Du JY, Aichmair A, Kueper J, Wright T, Lebl DR: Biomechanical analysis of screw constructs for atlantoaxial fixation in cadavers: a systematic review and meta-analysis. J Neurosurg Spine 22:151-161, 2015

43. Dubousset J, Herring JA, Shufflebarger H: The crankshaft phenomenon. J Pediatr Orthop 9:541-550, 1989

44. Dvorak MF, Kwon BK, Fisher CG, Eiserloh HL III, Boyd M, Wing PC: Effectiveness of titanium mesh cylindrical cages in anterior column reconstruction after thoracic and lumbar vertebral body resection. Spine (Phila Pa 1976) 28:902-908, 2003

45. Farey ID, Nadkarni S, Smith N: Modified Gallie technique versus transarticular screw fixation in $\mathrm{C} 1-\mathrm{C} 2$ fusion. Clin Orthop Relat Res (359): 126-135, 1999

46. Faure A, Monteiro R, Hamel O, Raoul S, Szapiro J, Alcheikh M, et al: Inverted-hook occipital clamp system in occipitocervical fixation. Technical note. J Neurosurg 97 (1 Suppl): 135-141, 2002

47. Fehlings MG, Cooper PR, Errico TJ: Posterior plates in the management of cervical instability: long-term results in 44 patients. J Neurosurg 81:341-349, 1994

48. Garber ST, Brockmeyer DL: Management of subaxial cervical instability in very young or small-for-age children using a static single-screw anterior cervical plate: indications, results, and long-term follow-up. J Neurosurg Spine 24:892-896, 2016

49. Ghiselli G, Wang JC, Bhatia NN, Hsu WK, Dawson EG: Adjacent segment degeneration in the lumbar spine. J Bone Joint Surg Am 86-A: 1497-1503, 2004

50. Gill K, Paschal S, Corin J, Ashman R, Bucholz RW: Posterior plating of the cervical spine. A biomechanical comparison of different posterior fusion techniques. Spine (Phila Pa 1976) 13:813-816, 1988

51. Girardi FP, Boachie-Adjei O, Rawlins BA: Safety of sublaminar wires with Isola instrumentation for the treatment of idiopathic scoliosis. Spine (Phila Pa 1976) 25:691-695, 2000

52. Gluf WM, Brockmeyer DL: Atlantoaxial transarticular screw fixation: a review of surgical indications, fusion rate, complications, and lessons learned in 67 pediatric patients. J Neurosurg Spine 2:164-169, 2005

53. Goel A, Laheri V: Plate and screw fixation for atlanto-axial subluxation. Acta Neurochir (Wien) 129:47-53, 1994

54. Goldstein HE, Neira JA, Banu M, Aldana PR, Braga BP, Brockmeyer DL, et al: Growth and alignment of the pediatric subaxial cervical spine following rigid instrumentation and fusion: a multicenter study of the Pediatric Craniocervical Society. J Neurosurg Pediatr 22:81-88, 2018

55. Grob D, Dvorak J, Panjabi MM, Antinnes JA: The role of plate and screw fixation in occipitocervical fusion in rheumatoid arthritis. Spine (Phila Pa 1976) 19:2545-2551, 1994

56. Haher TR, Yeung AW, Caruso SA, Merola AA, Shin T, Zipnick RI, et al: Occipital screw pullout strength. A biomechanical investigation of occipital morphology. Spine (Phila Pa 1976) 24:5-9, 1999

57. Harms J, Melcher RP: Posterior C1-C2 fusion with polyaxial screw and rod fixation. Spine (Phila Pa 1976) 26:24672471, 2001

58. Harrington PR: The history and development of Harrington instrumentation. Clin Orthop Relat Res (93):110-112, 1973

59. Harrington PR: Treatment of scoliosis. Correction and internal fixation by spine instrumentation. J Bone Joint Surg Am 44-A:591-610, 1962

60. Hedequist DJ, Hall JE, Emans JB: The safety and efficacy of spinal instrumentation in children with congenital spine deformities. Spine (Phila Pa 1976) 29:2081-2087, 2004

61. Hefti FL, McMaster MJ: The effect of the adolescent growth spurt on early posterior spinal fusion in infantile and juvenile idiopathic scoliosis. J Bone Joint Surg Br 65:247254, 1983

62. Herring JA, Wenger DR: Segmental spinal instrumentation: a preliminary report of 40 consecutive cases. Spine (Phila Pa 1976) 7:285-298, 1982

63. Heywood AW, Learmonth ID, Thomas M: Internal fixation for occipito-cervical fusion. J Bone Joint Surg Br 70:708711,1988

64. Holland CM, Kebriaei MA, Wrubel DM: Posterior cervical spinal fusion in a 3-week-old infant with a severe subaxial distraction injury. J Neurosurg Pediatr 17:353-356, 2016

65. Howington JU, Kruse JJ, Awasthi D: Surgical anatomy of the C-2 pedicle. J Neurosurg 95 (1 Suppl):88-92, 2001

66. Hwang SW, Gressot LV, Rangel-Castilla L, Whitehead WE, Curry DJ, Bollo RJ, et al: Outcomes of instrumented fusion in the pediatric cervical spine. J Neurosurg Spine 17:397409,2012 
67. Jain A, Kebaish KM, Sponseller PD: Factors associated with use of bone morphogenetic protein during pediatric spinal fusion surgery: an analysis of 4817 patients. J Bone Joint Surg Am 95:1265-1270, 2013

68. Jea A, Taylor MD, Dirks PB, Kulkarni AV, Rutka JT, Drake JM: Incorporation of C-1 lateral mass screws in occipitocervical and atlantoaxial fusions for children 8 years of age or younger. Technical note. J Neurosurg 107 (2 Suppl):178-183, 2007

69. Jeanneret B, Magerl F: Primary posterior fusion C1/2 in odontoid fractures: indications, technique, and results of transarticular screw fixation. J Spinal Disord 5:464-475, 1992

70. Jenks M, Craig J, Higgins J, Willits I, Barata T, Wood H, et al: The MAGEC system for spinal lengthening in children with scoliosis: a NICE medical technology guidance. Appl Health Econ Health Policy 12:587-599, 2014

71. Johnson KT, Al-Holou WN, Anderson RC, Wilson TJ, Karnati T, Ibrahim M, et al: Morphometric analysis of the developing pediatric cervical spine. J Neurosurg Pediatr 18:377-389, 2016

72. Johnston CE II, Happel LT Jr, Norris R, Burke SW, King AG, Roberts JM: Delayed paraplegia complicating sublaminar segmental spinal instrumentation. J Bone Joint Surg Am 68:556-563, 1986

73. Kamimura M, Ebara S, Itoh H, Tateiwa Y, Kinoshita T, Takaoka K: Accurate pedicle screw insertion under the control of a computer-assisted image guiding system: laboratory test and clinical study. J Orthop Sci 4:197-206, 1999

74. Kennedy BC, D'Amico RS, Youngerman BE, McDowell MM, Hooten KG, Couture D, et al: Long-term growth and alignment after occipitocervical and atlantoaxial fusion with rigid internal fixation in young children. J Neurosurg Pediatr 17:94-102, 2016

75. Kleinerman RA: Cancer risks following diagnostic and therapeutic radiation exposure in children. Pediatr Radiol 36 (Suppl 2):121-125, 2006

76. Klimo P Jr, Astur N, Gabrick K, Warner WC Jr, Muhlbauer MS: Occipitocervical fusion using a contoured rod and wire construct in children: a reappraisal of a vintage technique. $\mathbf{J}$ Neurosurg Pediatr 11:160-169, 2013

77. Kou I, Takahashi Y, Johnson TA, Takahashi A, Guo L, Dai $\mathrm{J}$, et al: Genetic variants in GPR126 are associated with adolescent idiopathic scoliosis. Nat Genet 45:676-679, 2013

78. Krag MH, Beynnon BD, Pope MH, Frymoyer JW, Haugh LD, Weaver DL: An internal fixator for posterior application to short segments of the thoracic, lumbar, or lumbosacral spine. Design and testing. Clin Orthop Relat Res (203):75-98, 1986

79. Kurtz SM, Devine JN: PEEK biomaterials in trauma, orthopedic, and spinal implants. Biomaterials 28:4845-4869, 2007

80. Kwan KYH, Alanay A, Yazici M, Demirkiran G, Helenius I, Nnadi C, et al: Unplanned reoperations in magnetically controlled growing rod surgery for early onset scoliosis with a minimum of two-year follow-up. Spine (Phila Pa 1976) 42:E1410-E1414, 2017

81. Lapinksy AS, Richards BS: Preventing the crankshaft phenomenon by combining anterior fusion with posterior instrumentation. Does it work? Spine (Phila Pa 1976) 20:1392-1398, 1995

82. Larson AN, Polly DW Jr, Guidera KJ, Mielke CH, Santos ER, Ledonio CG, et al: The accuracy of navigation and 3D image-guided placement for the placement of pedicle screws in congenital spine deformity. J Pediatr Orthop 32:e23-e29, 2012

83. Larson AN, Santos ER, Polly DW Jr, Ledonio CG, Sembrano JN, Mielke CH, et al: Pediatric pedicle screw placement using intraoperative computed tomography and 3-dimensional image-guided navigation. Spine (Phila Pa 1976) 37:E188-E194, 2012

84. Lee CS, Nachemson AL: The crankshaft phenomenon after posterior Harrington fusion in skeletally immature patients with thoracic or thoracolumbar idiopathic scoliosis followed to maturity. Spine (Phila Pa 1976) 22:58-67, 1997

85. Lee SM, Suk SI, Chung ER: Direct vertebral rotation: a new technique of three-dimensional deformity correction with segmental pedicle screw fixation in adolescent idiopathic scoliosis. Spine (Phila Pa 1976) 29:343-349, 2004

86. Lenke LG, Bridwell KH: Mesh cages in idiopathic scoliosis in adolescents. Clin Orthop Relat Res (394):98-108, 2002

87. Leonard JR, Wright NM: Pediatric atlantoaxial fixation with bilateral, crossing C-2 translaminar screws. Technical note. J Neurosurg 104 (1 Suppl):59-63, 2006

88. Li W, Li Y, Zhang L, Guo H, Tian D, Li Y, et al: AKAP2 identified as a novel gene mutated in a Chinese family with adolescent idiopathic scoliosis. J Med Genet 53:488-493, 2016

89. Liang J, Li S, Xu D, Zhuang Q, Ren Z, Chen X, et al: Risk factors for predicting complications associated with growing rod surgery for early-onset scoliosis. Clin Neurol Neurosurg 136: 15-19, 2015

90. Liljenqvist U, Lepsien U, Hackenberg L, Niemeyer T, Halm $\mathrm{H}$ : Comparative analysis of pedicle screw and hook instrumentation in posterior correction and fusion of idiopathic thoracic scoliosis. Eur Spine J 11:336-343, 2002

91. Liljenqvist UR, Halm HF, Link TM: Pedicle screw instrumentation of the thoracic spine in idiopathic scoliosis. Spine (Phila Pa 1976) 22:2239-2245, 1997

92. Lonstein JE, Winter RB, Moe JH, Bradford DS, Chou SN, Pinto WC: Neurologic deficits secondary to spinal deformity. A review of the literature and report of 43 cases. Spine (Phila Pa 1976) 5:331-355, 1980

93. Luque ER: Segmental spinal instrumentation for correction of scoliosis. Clin Orthop Relat Res (163):192-198, 1982

94. Madawi AA, Casey AT, Solanki GA, Tuite G, Veres R, Crockard HA: Radiological and anatomical evaluation of the atlantoaxial transarticular screw fixation technique. J Neurosurg 86:961-968, 1997

95. Majd ME, Castro FP Jr, Holt RT: Anterior fusion for idiopathic scoliosis. Spine (Phila Pa 1976) 25:696-702, 2000

96. Marchesi DG, Michel M, Lowery GL, Aebi M: Anterior transpedicular fixation of the lower thoracic and lumbar spine. Experimental verification using a new direction finder. Spine (Phila Pa 1976) 18:461-465, 1993

97. Martinez-Del-Campo E, Turner JD, Rangel-Castilla L, Soriano-Baron H, Kalb S, Theodore N: Pediatric occipitocervical fixation: radiographic criteria, surgical technique, and clinical outcomes based on experience of a single surgeon. J Neurosurg Pediatr 18:452-462, 2016

98. Martinez-Del-Campo E, Turner JD, Soriano-Baron H, Newcomb AG, Kalb S, Theodore N: Pediatric occipitocervical fusion: long-term radiographic changes in curvature, growth, and alignment. J Neurosurg Pediatr 18:644-652, 2016

99. McCarthy RE, McCullough FL: Shilla growth guidance for early-onset scoliosis: results after a minimum of five years of follow-up. J Bone Joint Surg Am 97:1578-1584, 2015

100. Mehlman CT, Araghi A, Roy DR: Hyphenated history: the Hueter-Volkmann law. Am J Orthop 26:798-800, 1997

101. Mente PL, Stokes IA, Spence H, Aronsson DD: Progression of vertebral wedging in an asymmetrically loaded rat tail model. Spine (Phila Pa 1976) 22:1292-1296, 1997

102. Merloz P, Tonetti J, Pittet L, Coulomb M, Lavallée S, Troccaz J, et al: Computer-assisted spine surgery. Comput Aided Surg 3:297-305, 1998

103. Montesano PX, Jauch E, Jonsson H Jr: Anatomic and bio- 
mechanical study of posterior cervical spine plate arthrodesis: an evaluation of two different techniques of screw placement. J Spinal Disord 5:301-305, 1992

104. Myles RT, Fong B, Esses SI, Hipp JA: Radiographic verification of pedicle screw pilot hole placement using Kirshner wires versus beaded wires. Spine (Phila Pa 1976) 24:476480, 1999

105. Nachlas IW, Borden JN: The cure of experimental scoliosis by directed growth control. J Bone Joint Surg Am 33-A:24-34, 1951

106. Nadim Y, Lu J, Sabry FF, Ebraheim N: Occipital screws in occipitocervical fusion and their relation to the venous sinuses: an anatomic and radiographic study. Orthopedics 23:717-719, 2000

107. Newton PO, Farnsworth CL, Faro FD, Mahar AT, Odell TR, Mohamad F, et al: Spinal growth modulation with an anterolateral flexible tether in an immature bovine model: disc health and motion preservation. Spine (Phila Pa 1976) 33:724-733, 2008

108. Newton PO, Fricka KB, Lee SS, Farnsworth CL, Cox TG, Mahar AT: Asymmetrical flexible tethering of spine growth in an immature bovine model. Spine (Phila Pa 1976) 27:689-693, 2002

109. Ni B, Guo X, Xie N, Lu X, Yuan W, Li S, et al: Bilateral atlantoaxial transarticular screws and atlas laminar hooks fixation for pediatric atlantoaxial instability. Spine (Phila Pa 1976) 35:E1367-E1372, 2010

110. Odent T, Bou Ghosn R, Dusabe JP, Zerah M, Glorion C: Internal fixation with occipital hooks construct for occipitocervical arthrodesis. Results in 14 young or small children. Eur Spine J 24:94-100, 2015

111. Ogura Y, Kou I, Miura S, Takahashi A, Xu L, Takeda K, et al: A functional SNP in BNC2 is associated with adolescent idiopathic scoliosis. Am J Hum Genet 97:337-342, 2015

112. Papagelopoulos PJ, Currier BL, Stone J, Grabowski JJ, Larson DR, Fisher DR, et al: Biomechanical evaluation of occipital fixation. J Spinal Disord 13:336-344, 2000

113. Parisini P, Di Silvestre M, Greggi T, Bianchi G: C1-C2 posterior fusion in growing patients: long-term follow-up. Spine (Phila Pa 1976) 28:566-572, 2003

114. Patten SA, Margaritte-Jeannin P, Bernard JC, Alix E, Labalme A, Besson A, et al: Functional variants of POC5 identified in patients with idiopathic scoliosis. J Clin Invest 125:1124-1128, 2015

115. Pennig D, Brug E: A target device for placement of implants in the thoracolumbar pedicles. J Bone Joint Surg Br 72:886-888, 1990

116. Quinn JC, Patel NV, Tyagi R: Hybrid lateral mass screw sublaminar wire construct: A salvage technique for posterior cervical fixation in pediatric spine surgery. J Clin Neurosci 25:118-121, 2016

117. Rajasekaran S, Kanna PR, Shetty AP: Safety of cervical pedicle screw insertion in children: a clinicoradiological evaluation of computer-assisted insertion of 51 cervical pedicle screws including 28 subaxial pedicle screws in 16 children. Spine (Phila Pa 1976) 37:E216-E223, 2012

118. Rangel-Castilla L, Hwang SW, Whitehead WE, Curry DJ, Luerssen TG, Jea A: Surgical treatment of thoracic Pott disease in a 3-year-old child, with vertebral column resection and posterior-only circumferential reconstruction of the spinal column: case report. J Neurosurg Pediatr 9:447-451, 2012

119. Resnick DK, Lapsiwala S, Trost GR: Anatomic suitability of the C1-C2 complex for pedicle screw fixation. Spine (Phila Pa 1976) 27:1494-1498, 2002

120. Richards BS, Johnston CE II: Cotrel-Dubousset instrumentation for adolescent idiopathic scoliosis. Orthopedics 10:649-654, 1987

121. Richardson AB, Taylor ML, Murphree B: TSRH instru- mentation: evolution of a new system. Part 1. Orthop Nurs 9:15-21, 1990

122. Riis J, Lehman RR, Perera RA, Quinn JR, Rinehart P, Tuten $\mathrm{HR}$, et al: A retrospective comparison of intraoperative CT and fluoroscopy evaluating radiation exposure in posterior spinal fusions for scoliosis. Patient Saf Surg 11:32, 2017

123. Roberts DA, Doherty BJ, Heggeness MH: Quantitative anatomy of the occiput and the biomechanics of occipital screw fixation. Spine (Phila Pa 1976) 23:1100-1108, 1998

124. Roy-Camille R, Saillant G, Laville C, Benazet JP: Treatment of lower cervical spinal injuries $-\mathrm{C} 3$ to C7. Spine (Phila Pa 1976) 17 (10 Suppl):S442-S446, 1992

125. Roy-Camille R, Saillant G, Mazel C: Internal fixation of the lumbar spine with pedicle screw plating. Clin Orthop Relat Res (203):7-17, 1986

126. Roy-Camille R, Saillant G, Mazel C: Plating of thoracic, thoracolumbar, and lumbar injuries with pedicle screw plates. Orthop Clin North Am 17:147-159, 1986

127. Ryken TC, Goel VK, Clausen JD, Traynelis VC: Assessment of unicortical and bicortical fixation in a quasistatic cadaveric model. Role of bone mineral density and screw torque. Spine (Phila Pa 1976) 20:1861-1867, 1995

128. Samdani AF, Ames RJ, Kimball JS, Pahys JM, Grewal H, Pelletier GJ, et al: Anterior vertebral body tethering for idiopathic scoliosis: two-year results. Spine (Phila Pa 1976) 39:1688-1693, 2014

129. Sanders JO, Little DG, Richards BS: Prediction of the crankshaft phenomenon by peak height velocity. Spine (Phila Pa 1976) 22:1352-1357, 1997

130. Savage JG, Fulkerson DH, Sen AN, Thomas JG, Jea A: Fixation with C-2 laminar screws in occipitocervical or C1-2 constructs in children 5 years of age or younger: a series of 18 patients. J Neurosurg Pediatr 14:87-93, 2014

131. Sayama C, Hadley C, Monaco GN, Sen A, Brayton A, Briceño $\mathrm{V}$, et al: The efficacy of routine use of recombinant human bone morphogenetic protein- 2 in occipitocervical and atlantoaxial fusions of the pediatric spine: a minimum of 12 months' follow-up with computed tomography. J Neurosurg Pediatr 16: 14-20, 2015

132. Sayama C, Willsey M, Chintagumpala M, Brayton A, Briceño V, Ryan SL, et al: Routine use of recombinant human bone morphogenetic protein-2 in posterior fusions of the pediatric spine and incidence of cancer. J Neurosurg Pediatr 16:4-13, 2015

133. Seitz H, Marlovits S, Schwendenwein I, Müller E, Vécsei $\mathrm{V}$ : Biocompatibility of polyethylene terephthalate (Trevira hochfest) augmentation device in repair of the anterior cruciate ligament. Biomaterials 19:189-196, 1998

134. Sekhon LH: Posterior cervical lateral mass screw fixation: analysis of 1026 consecutive screws in 143 patients. J Spinal Disord Tech 18:297-303, 2005

135. Sharma S, Londono D, Eckalbar WL, Gao X, Zhang D, Mauldin K, et al: A PAX1 enhancer locus is associated with susceptibility to idiopathic scoliosis in females. Nat Commun 6:6452, 2015

136. Singh B, Cree A: Laminar screw fixation of the axis in the pediatric population: a series of eight patients. Spine (Phila Pa 1976) J 15:e17-e25, 2015

137. Singh H, Rahimi SY, Yeh DJ, Floyd D: History of posterior thoracic instrumentation. Neurosurg Focus 16(1):E11, 2004

138. Sinha S, Jagetia A, Aher RB, Butte MK: Occiput/C1-C2 fixations using intra-laminar screw of axis-A long-term follow-up. Br J Neurosurg 29:260-264, 2015

139. Sinha S, Jagetia A, Bhausaheb AR, Butte MV, Jain R: Rigid variety occiput/C1-C2-C3 internal fixation in pediatric population. Childs Nerv Syst 30:257-269, 2014

140. Stauffer ES, Kelly EG: Fracture-dislocations of the cervical 
spine. Instability and recurrent deformity following treatment by anterior interbody fusion. J Bone Joint Surg Am 59: $45-48,1977$

141. Stevens DB, Beard C: Segmental spinal instrumentation for neuromuscular spinal deformity. Clin Orthop Relat Res (242):164-168, 1989

142. Strickland BA, Sayama C, Briceño V, Lam SK, Luerssen TG, Jea A: Use of subtransverse process polyester bands in pediatric spine surgery: a case series of 4 patients with a minimum of 12 months' follow-up. J Neurosurg Pediatr 17:208-214, 2016

143. Suk SI, Kim WJ, Lee SM, Kim JH, Chung ER: Thoracic pedicle screw fixation in spinal deformities: are they really safe? Spine (Phila Pa 1976) 26:2049-2057, 2001

144. Sutterlin CE III, McAfee PC, Warden KE, Rey RM Jr, Farey ID: A biomechanical evaluation of cervical spinal stabilization methods in a bovine model. Static and cyclical loading. Spine (Phila Pa 1976) 13:795-802, 1988

145. Tauchi R, Imagama S, Ito Z, Ando K, Muramoto A, Matsui $\mathrm{H}$, et al: Surgical treatment for chronic atlantoaxial rotatory fixation in children. J Pediatr Orthop B 22:404-408, 2013

146. Toyama Y, Matsumoto M, Chiba K, Asazuma T, Suzuki $\mathrm{N}$, Fujimura Y, et al: Realignment of postoperative cervical kyphosis in children by vertebral remodeling. Spine (Phila Pa 1976) 19:2565-2570, 1994

147. Turi M, Johnston CE II, Richards BS: Anterior correction of idiopathic scoliosis using TSRH instrumentation. Spine (Phila Pa 1976) 18:417-422, 1993

148. Ulrich C, Woersdoerfer O, Kalff R, Claes L, Wilke HJ: Biomechanics of fixation systems to the cervical spine. Spine (Phila Pa 1976) 16 (3 Suppl):S4-S9, 1991

149. Vaccaro AR, Balderston RA: Anterior plate instrumentation for disorders of the subaxial cervical spine. Clin Orthop Relat Res (335):112-121, 1997

150. Van de Kelft E, Costa F, Van der Planken D, Schils F: A prospective multicenter registry on the accuracy of pedicle screw placement in the thoracic, lumbar, and sacral levels with the use of the O-arm imaging system and StealthStation Navigation. Spine (Phila Pa 1976) 37:E1580-E1587, 2012

151. Vlach O, Grosman R, Rouchal M: [Instrumentation of idiopathic scolioses by isola and miami-moss systems.] Acta Chir Orthop Traumatol Cech 67:313-315, 2000 (Czech)

152. Wang JC, Nuccion SL, Feighan JE, Cohen B, Dorey FJ, Scoles PV: Growth and development of the pediatric cervical spine documented radiographically. J Bone Joint Surg Am 83-A: 1212-1218, 2001

153. Watanabe K, Uno K, Suzuki T, Kawakami N, Tsuji T, Yanagida H, et al: Risk factors for complications associated with growing-rod surgery for early-onset scoliosis. Spine (Phila Pa 1976) 38:E464-E468, 2013

154. Wimmer C, Gluch H, Franzreb M, Ogon M: Predisposing factors for infection in spine surgery: a survey of 850 spinal procedures. J Spinal Disord 11:124-128, 1998
155. Winegar CD, Lawrence JP, Friel BC, Fernandez C, Hong J, Maltenfort M, et al: A systematic review of occipital cervical fusion: techniques and outcomes. J Neurosurg Spine 13:5-16, 2010

156. Winter RB, Lonstein JE: Congenital scoliosis with posterior spinal arthrodesis T2-L3 at age 3 years with 41-year followup. A case report. Spine (Phila Pa 1976) 24:194-197, 1999

157. Winter RB, Moe JH: The results of spinal arthrodesis for congenital spinal deformity in patients younger than five years old. J Bone Joint Surg Am 64:419-432, 1982

158. Winter RB, Moe JH, Lonstein JE: Posterior spinal arthrodesis for congenital scoliosis. An analysis of the cases of two hundred and ninety patients, five to nineteen years old. J Bone Joint Surg Am 66:1188-1197, 1984

159. Wittenberg RH, Shea M, Swartz DE, Lee KS, White AA III, Hayes WC: Importance of bone mineral density in instrumented spine fusions. Spine (Phila Pa 1976) 16:647652,1991

160. Wright NM: Posterior C2 fixation using bilateral, crossing C2 laminar screws: case series and technical note. J Spinal Disord Tech 17:158-162, 2004

161. Wright NM: Translaminar rigid screw fixation of the axis. Technical note. J Neurosurg Spine 3:409-414, 2005

162. Zhou T, Chen C, Xu C, Zhou H, Gao B, Su D, et al: Mutant MAPK7-induced idiopathic scoliosis is linked to impaired osteogenesis. Cell Physiol Biochem 48:880-890, 2018

163. Zhu Z, Tang NL, Xu L, Qin X, Mao S, Song Y, et al: Genome-wide association study identifies new susceptibility loci for adolescent idiopathic scoliosis in Chinese girls. Nat Commun 6:8355, 2015

\section{Disclosures}

The authors report no conflict of interest concerning the materials or methods used in this study or the findings specified in this paper.

\section{Author Contributions}

Conception and design: Jea, Mendenhall, Mobasser. Acquisition of data: Jea, Mendenhall, Mobasser. Analysis and interpretation of data: Jea, Mendenhall, Mobasser. Drafting the article: Jea, Mendenhall, Mobasser. Critically revising the article: Jea, Mendenhall. Reviewed submitted version of manuscript: Jea, Mendenhall, Mobasser. Approved the final version of the manuscript on behalf of all authors: Jea. Administrative/technical/material support: all authors. Study supervision: Jea, Mendenhall, Mobasser. Illustrator: Relyea.

\section{Correspondence}

Andrew Jea: Goodman Campbell Brain and Spine, Indiana University School of Medicine, Indianapolis, IN. ajea@ goodmancampbell.com. 